\title{
Oil Prices and Stock Markets: An Empirical Analysis From Russia, Canada, USA and Japan*
}

\author{
Hasan KURTAR iD a Ayhan KAPUSUZOGLU iD b Nildag Basak CEYLAN iD c \\ aThe Scientific and Technological Research Council of Turkey, Kavaklidere, Ankara, Turkey. hasan.kurtar@tubitak.gov.tr \\ bAnkara Yildirim Beyazıt University, Faculty of Business, Department of Banking and Finance, Esenboga Campus, Ankara, Turkey. \\ akapusuzoglu@ybu.edu.tr \\ cAnkara Yildirim Beyazıt University, Faculty of Business, Department of Banking and Finance, Esenboga Campus, Ankara, Turkey. \\ $\underline{\text { nbceylan@ybu.edu.tr }}$
}

\begin{tabular}{|c|c|}
\hline ARTICLE INFO & ABSTRACT \\
\hline $\begin{array}{l}\text { Keywords: } \\
\text { Oil price }\end{array}$ & $\begin{array}{l}\text { Purpose - The aim of this study is to examine the relationship between oil prices and stock } \\
\text { markets at the aggregate and sector level in countries which have different characteristics. }\end{array}$ \\
\hline $\begin{array}{l}\text { Stock market } \\
\text { Sector indices } \\
\text { Cointegration }\end{array}$ & $\begin{array}{l}\text { Design/methodology/approach - The relationship among stock markets, sectoral stock indices } \\
\text { and oil price changes are examined for Russia and Canada which are net oil exporters and } \\
\text { United States and Japan which are net oil importers by using Johansen cointegration test. }\end{array}$ \\
\hline $\begin{array}{l}\text { Received } 2 \text { November } 2018 \\
\text { Revised } 28 \text { February } 2019 \\
\text { Accepted } 22 \text { March } 2019\end{array}$ & $\begin{array}{l}\text { Findings - The findings of this study show that there are significant and mostly positive } \\
\text { relationships between Russian MOEX stock market indices and crude oil prices. However; } \\
\text { significant Johansen cointegration between Brent Crude Oil prices and most of the Canadian, } \\
\text { U.S. and Japanese stock market aggregate and sectoral indices are not reported. }\end{array}$ \\
\hline $\begin{array}{l}\text { Article Classification: } \\
\text { Research Article }\end{array}$ & $\begin{array}{l}\text { Discussion - According to the findings, it can be stated that the long term relationship between } \\
\text { stock market indices and crude oil prices is related to the changing conditions in the profitability } \\
\text { of the corporations, inflation and monetary policy as a reaction to moving oil prices. }\end{array}$ \\
\hline
\end{tabular}

\section{Introduction}

Oil price impacts differ across countries as some of them are oil producers while others are oil consumers. Some countries are net oil exporters while some are net oil importers. Oil prices influence stock markets as well as macroeconomic indicators as it is income or cash inflow for some countries while it is cost or cash outflow for the others. Alterations in cash flow directly or indirectly will have some impacts on stock markets or equity values in stock markets as suggested by financial theory (Lardic \& Mignon, 2005). Influence of volatility in oil prices on the macroeconomic factors are examined in some studies such as Hamilton (1983), Gilbert and Mork (1984), Gisser and Goodwin (1986), Mork, (1989), Mork et al. (1994), Hooker (1996), Uri and Boyd (1997), Hamilton, (2003).

Before analyzing the relationship between oil prices and stock markets, it is necessary to create theoretical framework of the scope. First of all; oil prices affect economic activity significantly through six transmission mechanisms (Lardic and Mignon, 2005). Affected economic activity which has impact on profitability of firms, inflation and monetary policy influence stock markets as well. Six transmission mechanisms between oil prices and economic activity are supply-side effect, terms of trade effect, real balance effect, inflationary pressure theory, consumption-investment effect and long lasting oil price effect.

Supply side effect suggests that oil is one of the main production factors in the production process. When oil prices increase, costs of production rise and therefore potential output and productivity decrease significantly. Specifically; if firm faces unimagined alterations in their inventories, they try to bring to their inventories' level back to normal-old level. Meanwhile; when they face sudden increase in oil prices, their

\footnotetext{
${ }^{*}$ This paper is based on Hasan Kurtar's Master Thesis in Ankara Yildirim Beyazit University, Graduate School of Social Sciences, Ankara, Turkey. Moreover, this paper was orally presented at the XV. European Conference on Social and Behavioral Sciences held between February 1-3 2018, Aydin - Turkey and only the abstract is published in the conference proceedings. 
producing costs will go up as they bring their inventory level back to original. Therefore; firms reflect their increasing operational costs to output prices by increasing their sales prices. Reduction amount in inventories is vital for determining output price. If there is less decline in their inventories, their cost increase will also be less and this means lesser rise in their output prices. To summarize; rising oil prices will have negative impact on supply in all cases.

Terms of trade effect asserts that in case of an increase in oil prices, trade balance of oil importer countries is negatively influenced. Oil will be more expensive for oil importing countries and oil importing countries will have to pay more money for same amount of oil. This means an income transfer from oil importing countries to oil exporting countries. In addition; rising oil prices causes decline in purchasing power of firms and households in oil importing countries. On the other hand; rising oil prices will provide extra income for oil exporting countries as stated above. Oil exporting countries will be better off due to increasing oil prices because they will obtain more money for same amount of oil. To summarize; increasing oil prices will have some certain level of impact on terms of trade and it will be against favor of oil importing countries.

Real balance effect claims that increase in oil prices causes hike in money demand because oil importing countries (firms and households in oil importing country) will need more cash or money in order to buy same amount of oil. Increasing money demand will force economic units in oil importing countries to sell their bonds in order to fulfill their money demand according to the Keynesian theory. This will cause decline in prices of bonds as bond supply will have been increased. When bond prices go down; their yield or returns will rise. This means an increase in interest rates in oil importing countries. When this situation arises, central bank should intervene to the market and provide money to it. If central banks do not supply enough money which is need to meet increasing money demand, then interest rates rise. Increasing interest rates will increase cost of production and it will deteriorate investments in the economy since borrowing will be much more expensive. At the end; higher interest rates and increasing oil prices will influence economic activity negatively through various channels and this mechanism is called real balance effect.

Inflationary pressure theory offers that when oil prices go up inflationary process will be experienced since oil is a critical input for firms. Rising oil prices means an increase in cost of production as stated above. Firms will reflect this cost increase on their output prices and this means an increase in nominal prices. Employees or workers will react to this rising nominal prices by demanding increase in their nominal wages and this demand will cause an upward trend in firms' cost of productions once again. In return, increased wage raises cost of production and it forces firms to increase its sales prices. This process results in wage-price spiral which influences economic activity negatively. In addition; inflationary process is observed in the economy of oil importing countries meanwhile.

Consumption-investment effect suggests that increase in oil prices decreases disposable income and therefore consumption spending deteriorates. Specifically; rising oil prices means an extra income transferred from oil importing countries to oil exporting countries. Householders will have to pay more for the same amount of outputs since firms has raised their sales prices due to increase in cost of production coming with increasing oil prices. This situation means loss of income for householders in oil importing countries. In other words; householders' disposable income will be influenced negatively and it will go down in case of rising oil prices. To summarize; declining consumption spending and decreasing investments results in lower economic activity in oil importing economies ultimately.

Finally, long lasting price effect. This theory offers that if increase in oil prices becomes permanent, firms cannot bear with this continuous rise in costs. They always need to increase their sales price in each rise of oil prices. This continues increase in output prices of firms can mean loss of customers for firms. Therefore; they do not want to take risk of losing their customers for continuous inflation. To tackle with this problem; firms most probably change their production methods or structures in the long run. To summarize; economic activity is influenced from changes in oil prices through six mechanisms explained in details above. Economic activity is expected have negative influence on oil importing economies while it affects oil exporting economies positively according to the economic theory. 


\section{Literature}

This study focuses on the relationship between oil prices and stock markets by comparing oil importing countries (U.S. and Japan) and oil exporting countries (Russian Federation and Canada). In literature, there are many studies that examine the relationship between oil prices and stock markets at the aggregate level. For example; Hammoudeh and Eleisa (2004), Gjerde and Saettem (1999), Arouri and Rault (2012), Bashar (2006), Arouri et al. (2011), Zarour (2006), Arouri et al. (2010), Bjørnland (2008), Ravichandran and Alkhathlan (2010), Onour (2007), Naifar and Al Dohaiman (2013), Cunado and Gracia (2014), Al-Fayoumi (2009), Maghyereh and Al-Kandari (2007) and Arouri and Fouquau (2009) study the relationship between oil prices and stock markets in aggregate level for several countries. These researches analyze the relationship between oil prices and stock markets by only focusing on a country/group of country/only oil importing countries/only oil exporting countries. They do not compare oil importing and exporting countries with respect to aggregate relationship between oil prices and stock markets. However; there are many studies that examine the relationship between oil prices and stock markets in aggregate level by comparing oil importing and oil exporting countries. For example; Park and Ratti (2008) investigate the relationship between oil price fluctuations and stock markets for 13 European countries and the United States where some of the countries such as Norway are oil exporters while others are oil importers. O'Neill et al. (2008), Degiannakis et al. (2011) examine the relationship between oil prices and stock markets in overall level by comparing oil importing and oil exporting countries. However; studies mentioned above mostly do not study at the sectoral level. They have only observed their country sets in overall level. On the other hand; some researchers such as Scholtens and Yurtsever (2012), Arouri (2011), Arouri and Nguyen (2010), Khamis and Hamdan (2016) make their analyses at the sectoral level in a country or in a group of country such as Eurozone countries. Yet; these studies which make their analysis on sectoral level in oil exporting countries or Eurozone countries or a singular country do not compare and contrast oil importing and oil exporting countries with respect to the relationship between oil prices and stock markets.

In the literature there are many studies which only concentrate on the relationship between oil prices and stock markets at the aggregate level. In addition; some studies compare oil importing and oil exporting countries at the aggregate level with respect to interaction between oil prices and stock markets. Furthermore; there are some studies that concentrate only on oil exporting countries or Eurozone countries or a singular country in sectoral level analyses. However; to the best of our our knowledge, there is no study which compares oil importing and oil exporting countries with respect to the relationship between oil prices and stock markets in aggregate and sectoral level at the same time. Therefore; this study (it may be the first study) will contribute to the literature by comparing and contrasting oil importing countries and exporting countries with respect to relationship between oil prices and stock markets both in aggregate level and sectoral level simultaneously. In addition; country set in this study demonstrates distinct features with respect to oil/foreign oil dependency. Russian economy is less diversified than Canadian and U.S. economies. Japan economy displays high dependency on foreign oil. Therefore; it will be very interesting to see in this study how affection level of those countries' aggregate and sectoral indices differ from oil price changes. Now, it is unclear whether countries (Russia and Japan) which show high dependency or oil/foreign oil will be influenced more than Canada and U.S. (which are more diversified economies) or not. The result of this study will contribute to the litertaure on explaining how oil importing and oil exporting countries are influenced by oil price changes in aggregate and sectoral level. In addition; it will be clear that whether countries' different characteristics take role or not with respect to affection level from oil price changes.

The purpose of this study is to analyze the relationship between stock markets/sectoral stock indices and oil price changes in Russia, Canada, Japan and the U.S. These four countries are selected as they have different characteristics with respect to having energy sources and foreign energy dependencies. For example; Russia and Canada are net oil exporter countries while Russian economy is more dependent to oil. On the other hand; Japan and U.S. are net oil importer countries while Japan economy has high dependency on foreign oil energy.

\section{Data and Methodology}


H. Kurtar - A. Kapusuzoglu - N.B. Ceylan 11/1 (2019) 558-574

In the paper, daily closing value of sectoral stock indices, aggregate indices and Brent crude oil have been employed. Russian (MOEX) sectoral and aggregate stock indices for period 09:01:2007 to 30:12:2016 are used in the analysis. The relationships between U.S. S\&P 500 indices with oil prices are made for the period 30.04.2007 to 30:12:2016. Canadian TSX Capped indices' relationship with changing oil prices is analyzed by using data which is between 02:01:2007 and 30:12:2016 dates. TOPIX 17 Japan indices are used in this analysis in order to test the relationship between oil price movements and Japanese stock market and the data is between 10.12.2007 - 30.12.2016. the data for Brent Crude Oil is available for period between 02.01.2007 - 30.12.2016. The data of Russian sectoral stock indices and main RTS index is obtained from Moscow Stock Exchange Data Distribution System (http://www.moex.com/en/). The daily closing value of S\&P 500 index and S\&P 500 sectoral stock indices are derived from S\&P Dow Jones Indices Data Distribution System (http://www.spindices.com). The data related to Canadian Composite index and sectoral stock indices are gathered from the Toronto Stock Exchange Data Distribution System (http://www.tsx.com). The closing prices of Japanese sectoral and aggregate stocks are received from Tokyo Stock Exchange Data Cloud System (http://db-ec.jpx.co.jp). Finally; Europe Brent spot prices are obtained from the U.S. Energy Information Administration Data Distribution System (https://www.eia.gov). In the study, Brent crude oil prices are chosen since it is prevailing with respect to reflecting true value of crude oil in international markets. In methodology part, stationary analyses of data related with variables have been made in the study. Augmented Dickey-Fuller (ADF-1979) test and Phillips-Perron (PP-1988) test are performed for stationary analysis. In order to analyze long run relationship among series, Johansen (1988) cointegration test is applied.

Table 1. Daily Prices of Indices (2007-2016)

\begin{tabular}{|c|c|c|c|}
\hline \multicolumn{4}{|c|}{ Independent Variable } \\
\hline \multicolumn{4}{|c|}{ Europe Brent Crude Oil } \\
\hline \multicolumn{4}{|c|}{ Dependent Variable } \\
\hline USA & Russia & Canada & Japan \\
\hline S\&P500 Industrials & MOEX Main RTS & TSX Financials & $\begin{array}{c}\text { TOPIX } 17 \\
\text { Auto\&Transport. } \\
\text { Equip. } \\
\end{array}$ \\
\hline S\&P500 Information Tech. & MOEX Chemicals & TSX Health & TOPIX 17 Banks \\
\hline S\&P500 Materials & $\begin{array}{c}\text { MOEX Consumer } \\
\text { G\&S }\end{array}$ & TSX Industrial & $\begin{array}{c}\text { TOPIX } 17 \\
\text { Commercial\&Wholesale }\end{array}$ \\
\hline S\&P500 Real Estate & MOEX Electiric Util. & $\begin{array}{l}\text { TSX Information } \\
\text { Technologies }\end{array}$ & $\begin{array}{c}\text { TOPIX } 17 \\
\text { Construction\&Materials }\end{array}$ \\
\hline S\&P500 Telecom Services & MOEX Financials & TSX Materials & TOPIX 17 Electric App. \\
\hline S\&P500 Main & MOEX Oil\&Gas & TSX Real Estate & $\begin{array}{l}\text { TOPIX } 17 \text { Electric } \\
\text { Power\&Gas }\end{array}$ \\
\hline S\&P500 Consumer Disc. & $\begin{array}{c}\text { MOEX } \\
\text { Manufacturing }\end{array}$ & TSX REIT & $\begin{array}{l}\text { TOPIX } 17 \text { Energy } \\
\text { Resources }\end{array}$ \\
\hline S\&P500 Energy & $\begin{array}{c}\text { MOEX } \\
\text { Metals\&Mining }\end{array}$ & TSX Telecom Services & TOPIX 17 Foods \\
\hline S\&P500 Financials & MOEX Telecoms & TSX Utilities & TOPIX 17 Retail Trade \\
\hline S\&P500 Health Care & & TSX Composite & $\begin{array}{c}\text { TOPIX } 17 \\
\text { Steel\&Nonferrous } \\
\text { Metals }\end{array}$ \\
\hline S\&P500 Main & & TSX Consumer Disc. & $\begin{array}{c}\text { TOPIX } 17 \\
\text { Transport.\&Logistics }\end{array}$ \\
\hline S\&P500 Consumer Disc. & & TSX Energy & $\begin{array}{c}\text { TOPIX } 17 \\
\text { Auto\&Transport. } \\
\text { Equip. } \\
\end{array}$ \\
\hline S\&P500 Energy & & TSX Materials & TOPIX 17 Banks \\
\hline S\&P500 Financials & & TSX Real Estate & $\begin{array}{c}\text { TOPIX } 17 \\
\text { Commercial\&Wholesale }\end{array}$ \\
\hline
\end{tabular}


H. Kurtar - A. Kapusuzoglu - N.B. Ceylan 11/1 (2019) 558-574

\begin{tabular}{|c|c|}
\hline \multirow[t]{7}{*}{ S\&P500 Utilities } & $\begin{array}{c}\text { TOPIX } 17 \\
\text { Construction\&Materials }\end{array}$ \\
\hline & $\begin{array}{c}\text { TOPIX } 17 \\
\text { Pharmaceutical }\end{array}$ \\
\hline & $\begin{array}{c}\text { TOPIX17 Raw } \\
\text { Materials\&Chemicals }\end{array}$ \\
\hline & TOPIX 17 Real Estate \\
\hline & TOPIX 17 Machinery \\
\hline & $\begin{array}{c}\text { TOPIX } 17 \text { IT\&Services, } \\
\text { Others }\end{array}$ \\
\hline & TOPIX 17 Main \\
\hline
\end{tabular}

\section{Empirical Findings}

In the study, ADF and PP tests are used to test the stationary of the data. The results of the unit root tests shows that all variables except TOPIX 17 Energy Resource index (Japanese index) are unstationary at levels, I (0). More specifically; Russian MOEX Main, MOEX Chemicals, MOEX Consumer Goods \& Services, MOEX Electric Utilities, MOEX Financials, MOEX Manufacturing, MOEX Metals \& Mining, MOEX Oil \& Gas MOEX Telecoms, MOEX Transport indexes; U.S. SP500, SP500 Consumer Discretionary, SP500 Consumer Staples, SP500 Energy, SP500 Financials, SP500 Health Care, SP500 Industrials, SP500 Information Technology, SP500 Materials, SP500 Real Estate, SP500 Telecom Services, SP500 Utilities Indexes; Canadian TSX Capped Composite, TSX Capped Consumer Discretionary, TSX Capped Consumer Staples, TSX Capped Energy, TSX Capped Financials, TSX Capped Health Care, TSX Industrial, TSX Capped Information Technology, TSX Capped Materials, TSX Capped Real Estate, TSX Capped REIT, TSX Capped Telecom Services, TSX Capped Utilities indexes; Japanese TOPIX 17 Automobiles \& Transportation Equipments, TOPIX 17 Banks, TOPIX 17 Commercial \& Wholesale Trade, TOPIX 17 Construction Materials, TOPIX 17 Electric Appliances \& Precision Instruments, TOPIX 17 Electric Power \& Gas, TOPIX 17 Foods, TOPIX 17 IT Services \& Others, TOPIX 17 Machinery, TOPIX 17 Pharmaceutical, TOPIX 17 Raw Materials \& Chemicals, TOPIX 17 Real Estate, TOPIX 17 Retail Trade, TOPIX 17 Steel \& Nonferrous Metals, TOPIX 17 Transportation \& Logistics, TOPIX 17 Main indexes and Europe Brent Crude Oil prices are unstationary at their levels. In other words; their ADF and PP unit root tests statistics are smaller than critical values at I (0). ADF and PP unit root test statistics of TOPIX 17 Energy Resource are only values larger than critical value at I (0). Therefore; null hypothesis is rejected (there is unit root) only for TOPIX 17 Energy Resource. Null hypothesis for remaining variables cannot be rejected. This means that those remaining variables have unit root problem. Since unit root problem have been detected for all variables except TOPIX 17 Energy Resource index, first differences of the series have been taken to avoid this unit root problem. ADF and PP tests have been applied at their first differences. The results show that all variables become stationary at their first differences, I (1). ADF and PP test statistics at I (1) are larger than critical values. This means that null hypothesis can be easily rejected which asserts that there is unit root. To summarize; unit root problem has been solved in the series by taking first differences. This consequence shows that all variables except TOPIX 17 Energy Resource index are integrated from same (first) order. Since these variables are integrated at first (same) order, it is possible to look for the existence of long run relationship (cointegration) among the series.

Johansen cointegration analysis is used to test long relationship between crude oil price and sectoral and aggregate stock indices for series between 2007-2016. In determining the number of lags, a set of method such as Sequential Modified LR Test Statistic (each test at 5\% level), Final Prediction Error, Akaike Information, Hannan-Quinn Information, Schwarz Information criterions are considered and it is chosen by mutual decision of criterions. The results of the cointegration analyses are shown in Appendix (Table 3 - 10).

The results of the cointegration analysis shows that there is long run relationship between oil price and MOEX Main RTS, MOEX Chemicals, MOEX Electric Utilities, MOEX Financials, MOEX Metals \& Mining, MOEX Oil \& Gas, MOEX Telecoms, MOEX Transport, TSX Materials, TOPIX 17 Steel \& Nonferrous Metals Indexes for the period between 2007-2016. The results of the long run relationship is shown with cointegrating equation given below in Table 2.

Table 2. Long Run Relationship for Variables (2007-2016) 
H. Kurtar - A. Kapusuzoglu - N.B. Ceylan 11/1 (2019) 558-574

\begin{tabular}{|c|c|c|}
\hline \multirow{2}{*}{ Independent Variable (X) } & Dependent Variable (Y) & Cointegrating Equation \\
\hline \multirow{3}{*}{ Europe Brent Crude Oil Price } & MOEX Main RTS & $\mathrm{Y}=1047.438+2.051202 \mathrm{X}$ \\
\cline { 2 - 3 } & MOEX Chemicals & $\mathrm{Y}=0.070827+1.113165 \mathrm{X}$ \\
\hline \multirow{4}{*}{ Europe Brent Crude Oil Price } & MOEX Electric Utilities & $\mathrm{Y}=1154.551-14.06551 \mathrm{X}$ \\
\cline { 2 - 3 } & MOEX Financials & $\mathrm{Y}=470.0969-3.035067 \mathrm{X}$ \\
\cline { 2 - 3 } & MOEX Metals \& Mining & $\mathrm{Y}=332.3657-1.904497 \mathrm{X}$ \\
\cline { 2 - 3 } & MOEX Oil \& Gas & $\mathrm{Y}=132.5007+0.433166 \mathrm{X}$ \\
\cline { 2 - 3 } & MOEX Telecoms & $\mathrm{Y}=2.076062 \mathrm{X}$ \\
\cline { 2 - 3 } & MOEX Transport & $\mathrm{Y}=159.4034-1.172405 \mathrm{X}$ \\
\cline { 2 - 3 } & TSX Materials & $\mathrm{Y}=147.4951+1.739271 \mathrm{X}$ \\
\cline { 2 - 3 } & TOPIX 17 Steel \& Nonferrous Metals & $\mathrm{Y}=221.7550-0.405359 \mathrm{X}$ \\
\hline
\end{tabular}

The results of the analysis reported in Table 2 shows that most of the Russian indices have long run relationship with oil prices. The indices of the United States, Canada and Japan almost have no cointegration with oil prices in the long run. Specifically; there exists positive relationship between oil prices and MOEX main index. When oil price increases one unit, MOEX main index increases more than two units. Similarly; there is positive relationship between MOEX Chemicals, MOEX Oil Gas and MOEX Telecoms. If price of oil increases one unit, MOEX Chemical index increases more than one unit. Likewise; when oil prices increases by one unit, its reflection on MOEX Oil \& Gas index is around 0.4 unit. This value is greater in MOEX Telecoms index (which is more than 2 unit) in case of one-unit oil price increase. Lastly; positive relatonship is observed between Canadian TSX Materials index and oil price. When oil price increases by one unit, TSX Materials increases by 1.7 unit. There are also negative relationships between oil prices and MOEX Electric Utilities, MOEX Financials, MOEX Metals Mining MOEX Transport, TOPIX 17 Steel \& Nonferrous Metals. One-unit increase in oil price cause around 14-unit decline in MOEX Electric Utilities. The effect of one unit increase in oil price on MOEX Financials, MOEX Metals \& Mining MOEX Transport is around -3 units, -2 units and -1 unit respectively. Finally; while oil price increases 1 unit, there is decline around 0.4 unit in Japanese index, TOPIX 17 Steel \& Nonferrous Metals.

\section{Conclusion}

In this study; the relationship between four stock markets, namely; Russian, Canadian, Japanese and U.S., and oil prices have been analyzed. Among these four countries, two of them, Russia Federation and Canada, are oil exporting countries; while the other two countries, U.S. and Japan, are oil importing countries. According to the empirical findings, there are long run relationships between most of the MOEX (Russian) aggregate and sectoral stock indices and oil prices. For example; there is positive and long run association between MOEX Main Index and crude oil prices. Other positive long run relationships are observed between MOEX Chemicals-Crude Oil Price, MOEX Oil \& Gas-Crude Oil Price, MOEX Telecoms-Crude Oil Price. In addition; there are long run negative relationships are found between four MOEX (Russian) sector indices and crude oil prices. For example; MOEX Electric Utilities - Crude Oil Price, MOEX Financials - Crude Oil Price, MOEX Metals \& Mining - Crude Oil Price and MOEX Transport - Crude Oil Price have negative long run relationships according to the Johansen cointegration test results. In total, 8 out of 10 MOEX indices have long run relationship with crude oil prices. No cointegration between MOEX Consumer Goods \& Services Crude Oil Price and MOEX Manufacturing and Crude Oil Price are reported.

For Canada, long run positive relationship between TSX Materials index and crude oil price is reported. However; any long run association between Canadian stock market indices and crude oil prices could not be found except TSX Materials index.

For U.S., similar to Canada, no long run relationship between S\&P500 aggregate / sectoral indices and crude oil prices are found. The results suggest that the influence of crude oil price on S\&P 500 indices are very limited. It may be due to the well diversification of U.S. economy. The findings show that there is only long run negative relationship between oil price and Japanese TOPIX 17 Steel \& Nonferrous Metals. This negative relationship may be due to some reasons. Firstly; Japan is a net oil importing country, so negative relationship between Japanese stock market indices and crude oil prices is expected according to the financial and economic theory. Secondly; oil is a significant input for Steel \& Nonferrous Metals sector. 
H. Kurtar - A. Kapusuzoglu - N.B. Ceylan 11/1 (2019) 558-574

Increase in oil prices signals increase in costs for the sector, and thus negative relationship between the sector indices and oil price seem obvious.

It is interesting that there is no long run relationship between Japanese stock market indices and crude oil prices except for TOPIX 17 Steel \& Nonferrous Metals. Actually; Japan economy is highly dependent on foreign oil since the country is poor with respect to natural energy resources.

\section{References}

Al-Fayoumi, N. (2009). Oil prices and stock market returns in oil importing countries: The case of Turkey, Tunisia and Jordan, European Journal of Economics, Finance and Administrative Sciences, 16, 86-101.

Arouri, M.E.H. (2011). Does crude oil move stock markets in Europe? A sector investigation, Economic Modelling, 28 (4), 1716-1725.

Arouri, M.E. and Fouquau, J. (2009). On the shortterm influence of oil price changes on stock markets in GCC countries: Linear and nonlinear analyses, Economics Bulletin, AccessEcon, 29 (2) 795-804.

Arouri, M.E. and Nguyen, D.K. (2010). Oil prices, stock markets and portfolio investment: Evidence from sector analysis in Europe over the last decade, Energy Policy, 38 (8), 4528-4539.

Arouri, M.E. and Rault, C. (2012). Oil prices and stock markets in GCC countries: Empirical evidence from panel analysis, International Journal of Finance Economics, 17 (3), 242-253.

Arouri, M.E., Lahiani, A. and Bellalah, M. (2010). Oil price shocks and stock market returns in oil-exporting countries: The case of GCC countries, International Journal of Economics and Finance, 2 (5), 132-139.

Arouri, M.E., Lahiani, A. andNguyen, D.K. (2011). Return and volatility transmission between world oil prices and stock markets of the GCC countries, Economic Modelling, 28 (4), 1815-1825.

Bashar, A.Z. (2006). Wild oil prices, but brave stock markets! The case of GCC stock markets, Operational Research, 6 (2), 145-162.

Bjørnland, H.C. (2008). Oil ptice shocks and stock market booms in an oil exporting country, Working papers from Norges Bank, No: 16.

Cunado, J. and Gracia, F.P. (2014). Oil price shocks and stock market returns: Evidence for some European countries, Energy Economics, 42, 365-377.

Dickey, D.A. and Fuller, W.A. (1979). Distrubition of the estimators for autoregressive time series with a unit root, Journal of American Statistical Association, 74 (366), 427-431.

Filis, G., Degiannakis, S. and Floros, C. (2011). Dynamic correlation between stock market and oil prices: The case of oil-importing and oil-exporting countries, International Review of Financial Analysis, 20 (3), 152164.

Gilbert, R.J. and Mork, K.A. (1984). Will oil markets tighten again? A survey of policies to manage possible oil supply disruptions, Journal of Policy Modelling, 6 (1), 111-142.

Gisser, M. and Goodwin, T.H. (1986). Crude oil and the macroeconomy: Tests of some popular notions: Note, Journal of Money, Credit and Banking, 18 (1), 95-103.

Gjerde, Ø. and Sættem, F. (1999). Causal relations among stock returns and macroeconomic variables in a small, open economy, Journal of International Financial Markets, Institutions and Money, 9 (1), 61-74.

Hamilton, J. D. (1983). Oil and macroeconomy since World War II, Journal of Political Economy, 91 (2), 228-248.

Hamilton, J. D. (2003). What is an oil shock?, Journal of Econometrics, 113 (2), 363-398.

Hammoudeh, S. and Eleisa, L. (2004). Dynamic relationships among GCC stock markets and NYMEX oil futures, Contemporary Economic Policy, 22 (2), 250-269.

Hooker, M.A. (1996). What happened to the oil price-macroeconomy relationship?, Journal of Monetary Economics, 38 (2), 195-213. 
H. Kurtar - A. Kapusuzoglu - N.B. Ceylan 11/1 (2019) 558-574

Johansen, S. (1988). Statistical analysis of cointegration vectors, Journal of Economic Dynamics and Control, 12 (2-3), 231-254.

Khamis, R. and Hamdan, A. (2016). Sectoral response of GCC stock markets to international oil prices changes, London, United Kingdom (Access Date: 15 th $^{\text {th }}$ May 2017) https://www.dohainstitute.edu.qa/MEEA2016/Downloads/Reem\%20Khamis Final.pdf

Lardic, S. and Mignon, V. (2005). The impact of oil prices on GDP in European countries: An empirical investigation based on asymmetric cointegration, Energy Policy, 34 (18), 3910-3915.

Maghyereh, A. and Al-Kandari, A. (2007). Oil prices and stock markets in GCC countries: new evidence from nonlinear cointegration analysis, Managerial Finance, 33 (7), 449-460.

Mork, K.A. (1989). Oil and the macroeconomy when prices go up and down: An extension of Hamilton's results, Journal of Political Economy, 97 (3), 740-744.

Mork, K.A., Olsen, Ø. and Mysen, H.T. (1994). Macroeconomics responses to oil price increases and decreases in seven OECD countries, The Energy Journal, 15 (4), 19-35.

Naifar, N. and Dohaiman, M.S. (2013). Nonlinear analysis among crude oil prices, stock markets' return and macroeconomic variables, International Review of Economics $\mathcal{E}$ Finance, 27, 416-431.

O'Neill, T.J., Penm, J.H. and Terrell, R.D. (2008). The role of higher oil prices: A case of major developed countries, in Andrew H. Chen (ed.), Research in Finance, 24, 287-299.

Onour, I.A. (2007). Impact of oil price volatility on Gulf Cooperation Council stock markets' return, OPEC Energy Review, 31 (3), 171-189.

Park, J. and Ratti, R.A. (2008). Oil price shocks and stock markets in the U.S. and 13 European countries, Energy Economics, 30 (5), 2587-2608.

Phillips, P.C.B. and Perron, P. (1988). Testing for a unit root in time series regression, Biometrika, 75 (2), $335-$ 346.

Ravichandran, K. and Alkhathlan, K.A. (2010). Impact of oil prices on GCC stock market, Research in Applied Economics, 2 (1), 1-12.

Scholtens, B. and Yurtsever, C. (2012). Oil price shocks and European industries, Energy Economics, 34 (4), 1187-1195.

Uri, N.D. and Boyd, R. (1997). Economic impact of the energy price increase in Mexico, Environmental and Resource Economics, 10 (1), 101-107.

Zarour, B.A. (2006). Wild oil prices, but brave stock markets! The case of GCC stock markets, Operational Research, 6 (2), 145-162.

\section{APPENDIX}

Table 3. Johansen Cointegration Test Results-Trace Statistics (RUSSIA) 
H. Kurtar - A. Kapusuzoglu - N.B. Ceylan 11/1 (2019) 558-574

\begin{tabular}{|c|c|c|c|c|c|}
\hline Models & $\begin{array}{c}\text { Number of } \\
\text { CE(s) }\end{array}$ & $\begin{array}{l}\text { Eigen } \\
\text { Value }\end{array}$ & Trace Statistics & $\begin{array}{c}\% 5 \\
\text { Critical } \\
\text { Value }\end{array}$ & $\begin{array}{c}\text { \%1 } \\
\text { Critical } \\
\text { Value } \\
\end{array}$ \\
\hline \multirow{2}{*}{$\begin{array}{c}\text { Oil Price - MOEX } \\
\text { Main }\end{array}$} & None & 0.011210 & $\begin{array}{c}28.32997^{* * *}[3] \\
(0.0031)\end{array}$ & 20.26184 & 25.07811 \\
\hline & At most 1 & 0.004199 & $\begin{array}{c}7.699972[3] \\
(0.0941) \\
\end{array}$ & 9.164546 & 12.76076 \\
\hline \multirow{2}{*}{$\begin{array}{l}\text { Oil Price - MOEX } \\
\text { Chemicals }\end{array}$} & None & 0.010776 & $\begin{array}{c}27.65876^{* *}[2] \\
(0.0297) \\
\end{array}$ & 25.87211 & 31.15385 \\
\hline & At most 1 & 0.003329 & $\begin{array}{c}6.509100[2] \\
(0.3985) \\
\end{array}$ & 12.51798 & 16.55386 \\
\hline \multirow{2}{*}{$\begin{array}{c}\text { Oil Price - MOEX } \\
\text { Consumer Goods \& } \\
\text { Services }\end{array}$} & None & 0.008340 & $\begin{array}{c}20.45514[5] \\
\quad(0.2038) \\
\end{array}$ & 25.87211 & 31.15385 \\
\hline & At most 1 & 0.001923 & $\begin{array}{c}3.822331[5] \\
(0.7677) \\
\end{array}$ & 12.51798 & 16.55386 \\
\hline \multirow{2}{*}{$\begin{array}{l}\text { Oil Price - MOEX } \\
\text { Electric Utilities }\end{array}$} & None & 0.009708 & $\begin{array}{l}23.78377^{* *}[4] \\
(0.0157)\end{array}$ & 20.26184 & 25.07811 \\
\hline & At most 1 & 0.004088 & $\begin{array}{c}7.033573[4] \\
(0.1246) \\
\end{array}$ & 9.164546 & 12.76076 \\
\hline \multirow{2}{*}{$\begin{array}{l}\text { Oil Price }- \text { MOEX } \\
\text { Financials }\end{array}$} & None & 0.013122 & $\begin{array}{c}28.91457^{* * *}[3] \\
(0.0025)\end{array}$ & 20.26184 & 25.07811 \\
\hline & At most 1 & 0.002588 & $\begin{array}{c}4.742693[3] \\
(0.3128)\end{array}$ & 9.164546 & 12.76076 \\
\hline \multirow{2}{*}{$\begin{array}{c}\text { Oil Price - MOEX } \\
\text { Manufacturing }\end{array}$} & None & 0.004088 & $\begin{array}{c}14.85908[7] \\
(0.2345) \\
\end{array}$ & 20.26184 & 25.07811 \\
\hline & At most 1 & 0.003830 & $\begin{array}{c}7.187013 \text { [7] } \\
(0.1169) \\
\end{array}$ & 9.164546 & 12.76076 \\
\hline \multirow{2}{*}{$\begin{array}{l}\text { Oil Price - MOEX } \\
\text { Metals \& Mining }\end{array}$} & None & 0.012106 & $\begin{array}{c}29.76713^{* * *}[3] \\
(0.0018)\end{array}$ & 20.26184 & 25.07811 \\
\hline & At most 1 & 0.004078 & $\begin{array}{c}7.477936[3] \\
(0.1034) \\
\end{array}$ & 9.164546 & 12.76076 \\
\hline \multirow{2}{*}{$\begin{array}{l}\text { Oil Price - MOEX Oil } \\
\qquad \& \text { Gas }\end{array}$} & None & 0.019200 & $\begin{array}{c}35.24207^{* * *}[6] \\
(0.0002)\end{array}$ & 20.26184 & 25.07811 \\
\hline & At most 1 & 0.004053 & $\begin{array}{c}6.104422[6] \\
(0.1828) \\
\end{array}$ & 9.164546 & 12.76076 \\
\hline \multirow{2}{*}{$\begin{array}{c}\text { Oil Price - MOEX } \\
\text { Telecoms }\end{array}$} & None & 0.010626 & $\begin{array}{c}27.22403^{* *}[3] \\
(0.0338) \\
\end{array}$ & 25.87211 & 31.15385 \\
\hline & At most 1 & 0.002248 & $\begin{array}{c}4.736592[3] \\
(0.6345) \\
\end{array}$ & 12.51798 & 16.55386 \\
\hline \multirow{2}{*}{$\begin{array}{c}\text { Oil Price - MOEX } \\
\text { Transport }\end{array}$} & None & 0.013652 & $\begin{array}{c}26.07000^{* * *}[6] \\
(0.0070)\end{array}$ & 20.26184 & 25.07811 \\
\hline & At most 1 & 0.002110 & $\begin{array}{c}3.471736[6] \\
(0.4964)\end{array}$ & 9.164546 & 12.76076 \\
\hline
\end{tabular}

Table 4. Johansen Cointegration Test Results-Trace Statistics (USA)

\begin{tabular}{|l|l|l|l|l|l|} 
Models & Number & Eigen & Trace Statistics & $\% 5$ Critical & $\% 1$ Critical \\
\hline
\end{tabular}


H. Kurtar - A. Kapusuzoglu - N.B. Ceylan 11/1 (2019) 558-574

\begin{tabular}{|c|c|c|c|c|c|}
\hline & of $\mathrm{CE}(\mathrm{s})$ & Value & & Value & Value \\
\hline \multirow{2}{*}{ Oil Price - SP500 Index } & None & 0.001468 & $\begin{array}{c}4.876267[3] \\
(0.9841)\end{array}$ & 20.26184 & 25.07811 \\
\hline & At most 1 & 0.000544 & $\begin{array}{c}1.317817[3] \\
(0.9047) \\
\end{array}$ & 9.164546 & 12.76076 \\
\hline \multirow{2}{*}{$\begin{array}{c}\text { Oil Price - SP500 } \\
\text { Consumer } \\
\text { Discretionary }\end{array}$} & None & 0.005930 & $\begin{array}{c}17.30820[3] \\
(0.3923) \\
\end{array}$ & 25.87211 & 31.15385 \\
\hline & At most 1 & 0.001318 & $\begin{array}{c}3.141749[3] \\
(0.8592)\end{array}$ & 12.51798 & 16.55386 \\
\hline \multirow{2}{*}{$\begin{array}{l}\text { Oil Price - SP500 } \\
\text { Consumer Staples }\end{array}$} & None & 0.002727 & $\begin{array}{c}9.113418[3] \\
(0.7256) \\
\end{array}$ & 20.26184 & 25.07811 \\
\hline & At most 1 & 0.001094 & $\begin{array}{c}2.608516[3] \\
(0.6561) \\
\end{array}$ & 9.164546 & 12.76076 \\
\hline \multirow{2}{*}{$\begin{array}{l}\text { Oil Price - SP500 } \\
\text { Energy }\end{array}$} & None & 0.002033 & $\begin{array}{c}6.271353[3] \\
(0.9377) \\
\end{array}$ & 20.26184 & 25.07811 \\
\hline & At most 1 & 0.000514 & $\begin{array}{c}1.264138[3] \\
(0.9134)\end{array}$ & 9.164546 & 12.76076 \\
\hline \multirow{2}{*}{$\begin{array}{l}\text { Oil Price - SP500 } \\
\text { Financials }\end{array}$} & None & 0.002566 & $\begin{array}{c}9.022727[7] \\
(0.7342)\end{array}$ & 20.26184 & 25.07811 \\
\hline & At most 1 & 0.001023 & $\begin{array}{c}2.571151[7] \\
(0.6634) \\
\end{array}$ & 9.164546 & 12.76076 \\
\hline \multirow{2}{*}{$\begin{array}{l}\text { Oil Price - SP500 } \\
\text { Health Care }\end{array}$} & None & 0.003840 & $\begin{array}{c}10.87805[3] \\
(0.5539) \\
\end{array}$ & 20.26184 & 25.07811 \\
\hline & At most 1 & 0.000719 & $\begin{array}{c}1.713253[3] \\
(0.8338)\end{array}$ & 9.164546 & 12.76076 \\
\hline \multirow{2}{*}{$\begin{array}{l}\text { Oil Price - SP500 } \\
\text { Industrials }\end{array}$} & None & 0.001361 & $\begin{array}{c}4.289315[2] \\
(0.9929) \\
\end{array}$ & 20.26184 & 25.07811 \\
\hline & At most 1 & 0.000448 & $\begin{array}{c}1.061794[2] \\
(0.9434)\end{array}$ & 9.164546 & 12.76076 \\
\hline \multirow{2}{*}{$\begin{array}{l}\text { Oil Price - SP500 } \\
\text { Information } \\
\text { Technology }\end{array}$} & None & 0.003647 & $\begin{array}{c}10.22167[2] \\
(0.6180) \\
\end{array}$ & 20.26184 & 25.07811 \\
\hline & At most 1 & 0.000659 & $\begin{array}{c}1.562294[2] \\
(0.8621) \\
\end{array}$ & 9.164546 & 12.76076 \\
\hline \multirow{2}{*}{$\begin{array}{l}\text { Oil Price - SP500 } \\
\text { Materials }\end{array}$} & None & 0.001602 & $\begin{array}{c}4.498318[2] \\
(0.9903) \\
\end{array}$ & 20.26184 & 25.07811 \\
\hline & At most 1 & 0.000295 & $\begin{array}{c}0.698336[2] \\
(0.9828) \\
\end{array}$ & 9.164546 & 12.76076 \\
\hline \multirow{2}{*}{$\begin{array}{c}\text { Oil Price - SP500 Real } \\
\text { Estate }\end{array}$} & None & 0.001246 & $\begin{array}{c}4.258823[2] \\
(0.9932)\end{array}$ & 20.26184 & 25.07811 \\
\hline & At most 1 & 0.000532 & $\begin{array}{c}1.274228[2] \\
(0.9118) \\
\end{array}$ & 9.164546 & 12.76076 \\
\hline \multirow{2}{*}{$\begin{array}{l}\text { Oil Price - SP500 } \\
\text { Telecom Services }\end{array}$} & None & 0.001432 & $\begin{array}{c}4.532636[4] \\
(0.9899) \\
\end{array}$ & 20.26184 & 25.07811 \\
\hline & At most 1 & 0.000511 & $\begin{array}{c}1.191979[4] \\
(0.9246) \\
\end{array}$ & 9.164546 & 12.76076 \\
\hline \multirow{2}{*}{$\begin{array}{l}\text { Oil Price - SP500 } \\
\text { Utilities }\end{array}$} & None & 0.001533 & $\begin{array}{c}4.612693[2] \\
(0.9887)\end{array}$ & 20.26184 & 25.07811 \\
\hline & At most 1 & 0.000393 & $\begin{array}{l}0.940516[2] \\
(0.9588)\end{array}$ & 9.164546 & 12.76076 \\
\hline
\end{tabular}

Table 5. Johansen Cointegration Test Results-Trace Statistics (CANADA)

\begin{tabular}{|l|c|c|c|c|c|} 
Models & Number & Eigen & Trace Statistics & $\% 5$ Critical & $\% 1$ \\
\hline
\end{tabular}


H. Kurtar - A. Kapusuzoglu - N.B. Ceylan 11/1 (2019) 558-574

\begin{tabular}{|c|c|c|c|c|c|}
\hline & of $\mathrm{CE}(\mathrm{s})$ & Value & & Value & $\begin{array}{l}\text { Critical } \\
\text { Value }\end{array}$ \\
\hline \multirow{2}{*}{$\begin{array}{l}\text { Oil Price - TSX } \\
\text { Composite Index }\end{array}$} & None & 0.002226 & $\begin{array}{c}6.280380[7] \\
(0.9373) \\
\end{array}$ & 20.26184 & 25.07811 \\
\hline & At most 1 & 0.000276 & $\begin{array}{c}0.692559[7] \\
(0.9833) \\
\end{array}$ & 9.164546 & 12.76076 \\
\hline \multirow{2}{*}{$\begin{array}{c}\text { Oil Price - TSX } \\
\text { Consumer } \\
\text { Discretionary }\end{array}$} & None & 0.001769 & $\begin{array}{c}5.836107[2] \\
(0.9565)\end{array}$ & 20.26184 & 25.07811 \\
\hline & At most 1 & 0.000555 & $\begin{array}{c}1.393673[2] \\
(0.8920) \\
\end{array}$ & 9.164546 & 12.76076 \\
\hline \multirow{2}{*}{$\begin{array}{c}\text { Oil Price - TSX } \\
\text { Consumer Staples }\end{array}$} & None & 0.004495 & $\begin{array}{c}16.01106[6] \\
(0.1739)\end{array}$ & 20.26184 & 25.07811 \\
\hline & At most 1 & 0.001885 & $\begin{array}{c}4.725382[6] \\
(0.3149) \\
\end{array}$ & 9.164546 & 12.76076 \\
\hline \multirow{2}{*}{ Oil Price - TSX Energy } & None & 0.004305 & $\begin{array}{c}14.63234[7] \\
(0.2482)\end{array}$ & 20.26184 & 25.07811 \\
\hline & At most 1 & 0.001528 & $\begin{array}{c}3.828433[7] \\
(0.4382) \\
\end{array}$ & 9.164546 & 12.76076 \\
\hline \multirow{2}{*}{$\begin{array}{l}\text { Oil Price - TSX } \\
\text { Financials }\end{array}$} & None & 0.001798 & $\begin{array}{c}5.154004[7] \\
(0.9779) \\
\end{array}$ & 20.26184 & 25.07811 \\
\hline & At most 1 & 0.000257 & $\begin{array}{c}0.644917[7] \\
(0.9868) \\
\end{array}$ & 9.164546 & 12.76076 \\
\hline \multirow{2}{*}{$\begin{array}{c}\text { Oil Price - TSX Health } \\
\text { Care }\end{array}$} & None & 0.002559 & $\begin{array}{c}9.034443[4] \\
(0.7331) \\
\end{array}$ & 20.26184 & 25.07811 \\
\hline & At most 1 & 0.001041 & $\begin{array}{c}2.609944[4] \\
(0.6558)\end{array}$ & 9.164546 & 12.76076 \\
\hline \multirow{2}{*}{$\begin{array}{l}\text { Oil Price - TSX } \\
\text { Industrial }\end{array}$} & None & 0.001812 & $\begin{array}{c}6.741646[2] \\
(0.9129) \\
\end{array}$ & 20.26184 & 25.07811 \\
\hline & At most 1 & 0.000873 & $\begin{array}{l}2.191882[2] \\
\quad(0.7393)\end{array}$ & 9.164546 & 12.76076 \\
\hline \multirow{2}{*}{$\begin{array}{c}\text { Oil Price - TSX } \\
\text { Information } \\
\text { Technology }\end{array}$} & None & 0.002365 & $\begin{array}{c}6.419914[2] \\
(0.9304) \\
\end{array}$ & 20.26184 & 25.07811 \\
\hline & At most 1 & 0.000190 & $\begin{array}{c}0.477940[2] \\
(0.9956) \\
\end{array}$ & 9.164546 & 12.76076 \\
\hline \multirow{2}{*}{$\begin{array}{l}\text { Oil Price - TSX } \\
\text { Materials }\end{array}$} & None & 0.006525 & $\begin{array}{c}23.34761^{* *}[3] \\
(0.0182)\end{array}$ & 20.26184 & 25.07811 \\
\hline & At most 1 & 0.002755 & $\begin{array}{c}6.921828[3] \\
(0.1306) \\
\end{array}$ & 9.164546 & 12.76076 \\
\hline \multirow{2}{*}{$\begin{array}{c}\text { Oil Price - TSX Real } \\
\text { Estate }\end{array}$} & None & 0.001157 & $\begin{array}{c}3.400853[2] \\
(0.9987)\end{array}$ & 20.26184 & 25.07811 \\
\hline & At most 1 & 0.000197 & $\begin{array}{c}0.495213[2] \\
(0.9949) \\
\end{array}$ & 9.164546 & 12.76076 \\
\hline \multirow{2}{*}{ Oil Price - TSX REIT } & None & 0.001718 & $\begin{array}{c}5.260110[2] \\
(0.9752) \\
\end{array}$ & 20.26184 & 25.07811 \\
\hline & At most 1 & 0.000670 & $\begin{array}{c}1.474692[2] \\
(0.8779) \\
\end{array}$ & 9.164546 & 12.76076 \\
\hline \multirow{2}{*}{$\begin{array}{l}\text { Oil Price - TSX } \\
\text { Telecom. Services }\end{array}$} & None & 0.002193 & $\begin{array}{c}4.796347[1] \\
(0.9856) \\
\end{array}$ & 20.26184 & 25.07811 \\
\hline & At most 1 & 0.000132 & $\begin{array}{c}0.272020[1] \\
(0.9997) \\
\end{array}$ & 9.164546 & 12.76076 \\
\hline $\begin{array}{c}\text { Oil Price - TSX } \\
\text { Utilities }\end{array}$ & None & 0.001663 & $\begin{array}{c}5.411873[7] \\
(0.9709)\end{array}$ & 20.26184 & 25.07811 \\
\hline
\end{tabular}


H. Kurtar - A. Kapusuzoglu - N.B. Ceylan 11/1 (2019) 558-574

\begin{tabular}{|l|c|c|c|c|c|}
\hline & At most 1 & 0.000737 & $\begin{array}{c}1.660909[7] \\
(0.8438)\end{array}$ & 9.164546 & 12.76076 \\
\hline
\end{tabular}

Table 6. Johansen Cointegration Test Results-Trace Statistics (JAPAN)

\begin{tabular}{|c|c|c|c|c|c|}
\hline Models & $\begin{array}{l}\text { Number } \\
\text { of CE(s) }\end{array}$ & $\begin{array}{l}\text { Eigen } \\
\text { Value }\end{array}$ & Trace Statistics & $\begin{array}{l}\% 5 \text { Critical } \\
\text { Value }\end{array}$ & $\begin{array}{c}\text { \%1 Critical } \\
\text { Value }\end{array}$ \\
\hline \multirow{2}{*}{$\begin{array}{c}\text { Oil Price - TOPIX } 17 \\
\text { Auto \& Transport } \\
\text { Equipment }\end{array}$} & None & 0.000887 & $\begin{array}{c}1.461035[4] \\
(1.0000)\end{array}$ & 20.26184 & 25.07811 \\
\hline & At most 1 & 5.15E-06 & $\begin{array}{c}0.008430[4] \\
(1.0000)\end{array}$ & 9.164546 & 12.76076 \\
\hline \multirow{2}{*}{$\begin{array}{c}\text { Oil Price - TOPIX } 17 \\
\text { Banks }\end{array}$} & None & 0.013255 & $\begin{array}{c}18.98928[4] \\
(0.2814)\end{array}$ & 25.87211 & 31.15385 \\
\hline & At most 1 & 0.000133 & $\begin{array}{c}0.187472[4] \\
(1.0000)\end{array}$ & 12.51798 & 16.55386 \\
\hline \multirow{2}{*}{$\begin{array}{c}\text { Oil Price - TOPIX } 17 \\
\text { Commerce } \\
\text { Wholesale Trade }\end{array}$} & None & 0.002192 & $\begin{array}{c}4.843175[2] \\
(0.9847)\end{array}$ & 20.26184 & 25.07811 \\
\hline & At most 1 & 0.000703 & $\begin{array}{c}1.175850[2] \\
(0.9270)\end{array}$ & 9.164546 & 12.76076 \\
\hline \multirow{2}{*}{$\begin{array}{l}\text { Oil Price - TOPIX } 17 \\
\text { Construction } \\
\text { Materials }\end{array}$} & None & 0.009028 & $\begin{array}{c}15.65879[2] \\
(0.5202) \\
\end{array}$ & 25.87211 & 31.15385 \\
\hline & At most 1 & 0.000302 & $\begin{array}{c}0.504258[2] \\
(1.0000)\end{array}$ & 12.51798 & 16.55386 \\
\hline \multirow{2}{*}{$\begin{array}{l}\text { Oil Price - TOPIX } 17 \\
\text { Electrc App \& Prec } \\
\text { Instrmnt }\end{array}$} & None & 0.008386 & $\begin{array}{c}14.59646[2] \\
(0.6081)\end{array}$ & 25.87211 & 31.15385 \\
\hline & At most 1 & 0.000314 & $\begin{array}{c}0.523984[2] \\
(1.0000)\end{array}$ & 12.51798 & 16.55386 \\
\hline \multirow{2}{*}{$\begin{array}{l}\text { Oil Price - TOPIX } 17 \\
\text { Electric Power \& Gas }\end{array}$} & None & 0.005686 & $\begin{array}{c}10.11852[2] \\
(0.6282)\end{array}$ & 20.26184 & 25.07811 \\
\hline & At most 1 & 0.000353 & $\begin{array}{c}0.590431[2] \\
(0.9902)\end{array}$ & 9.164546 & 12.76076 \\
\hline \multirow{2}{*}{$\begin{array}{c}\text { Oil Price - TOPIX } 17 \\
\text { Foods }\end{array}$} & None & 0.001188 & $\begin{array}{c}2.094200[2] \\
(1.0000)\end{array}$ & 20.26184 & 25.07811 \\
\hline & At most 1 & $6.48 \mathrm{E}-05$ & $\begin{array}{c}0.108278[2] \\
(1.0000)\end{array}$ & 9.164546 & 12.76076 \\
\hline \multirow{2}{*}{$\begin{array}{l}\text { Oil Price - TOPIX } 17 \\
\text { IT \& Services \& } \\
\text { Others }\end{array}$} & None & 0.000551 & $\begin{array}{c}0.977246[4] \\
(1.0000) \\
\end{array}$ & 20.26184 & 25.07811 \\
\hline & At most 1 & 0.000138 & $\begin{array}{c}0.196298[4] \\
(1.0000)\end{array}$ & 9.164546 & 12.76076 \\
\hline \multirow{2}{*}{$\begin{array}{c}\text { Oil Price - TOPIX } 17 \\
\text { Machinery }\end{array}$} & None & 0.000887 & $\begin{array}{c}2.254741[2] \\
(1.0000)\end{array}$ & 20.26184 & 25.07811 \\
\hline & At most 1 & 0.000462 & $\begin{array}{c}0.771857[2] \\
(0.9766) \\
\end{array}$ & 9.164546 & 12.76076 \\
\hline \multirow{2}{*}{$\begin{array}{l}\text { Oil Price - TOPIX } 17 \\
\text { Pharmaceutical }\end{array}$} & None & 0.000925 & $\begin{array}{c}1.689529[2] \\
(1.0000)\end{array}$ & 20.26184 & 25.07811 \\
\hline & At most 1 & 8.69E-05 & $\begin{array}{c}0.145089[2] \\
(1.0000)\end{array}$ & 9.164546 & 12.76076 \\
\hline \multirow{2}{*}{$\begin{array}{c}\text { Oil Price - TOPIX } 17 \\
\text { Raw Materials \& } \\
\text { Chemicals }\end{array}$} & None & 0.010837 & $\begin{array}{c}15.65654[4] \\
(0.5203)\end{array}$ & 25.87211 & 31.15385 \\
\hline & At most 1 & 0.000145 & $\begin{array}{c}0.206253[4] \\
(1.0000)\end{array}$ & 12.51798 & 16.55386 \\
\hline $\begin{array}{l}\text { Oil Price - TOPIX } 17 \\
\text { Real Estate }\end{array}$ & None & 0.001267 & $\begin{array}{c}3.005253[2] \\
(0.9995)\end{array}$ & 20.26184 & 25.07811 \\
\hline
\end{tabular}


H. Kurtar - A. Kapusuzoglu - N.B. Ceylan 11/1 (2019) 558-574

\begin{tabular}{|l|c|c|c|c|c|}
\hline & At most 1 & 0.000535 & $\begin{array}{c}0.892409[2] \\
(0.9644)\end{array}$ & 9.164546 & 12.76076 \\
\hline \multirow{2}{*}{$\begin{array}{c}\text { Oil Price - TOPIX 17 } \\
\text { Retail Trade }\end{array}$} & None & 0.000747 & $\begin{array}{c}1.864968[2] \\
(1.0000)\end{array}$ & 20.26184 & 25.07811 \\
\cline { 2 - 6 } & At most 1 & 0.000369 & $\begin{array}{c}0.617037[2] \\
(0.9886)\end{array}$ & 9.164546 & 12.76076 \\
\hline $\begin{array}{c}\text { Oil Price - TOPIX 17 } \\
\text { Steel \& Nonferrous } \\
\text { Metals }\end{array}$ & None & 0.024992 & $\begin{array}{c}27.98719^{* * *}[7] \\
(0.0035)\end{array}$ & 20.26184 & 25.07811 \\
\cline { 2 - 6 } & At most 1 & 0.000227 & $\begin{array}{c}0.248396[7] \\
(0.9998)\end{array}$ & 9.164546 & 12.76076 \\
\hline $\begin{array}{l}\text { Oil Price - TOPIX 17 } \\
\text { Transportation \& } \\
\text { Logistics }\end{array}$ & None & 0.000361 & $\begin{array}{c}1.193124[1] \\
(1.0000)\end{array}$ & 20.26184 & 25.07811 \\
\cline { 2 - 6 } & At most 1 & 0.000294 & $\begin{array}{c}0.535311[1] \\
(0.9932)\end{array}$ & 9.164546 & 12.76076 \\
\hline \multirow{2}{*}{$\begin{array}{c}\text { Oil Price - TOPIX 17 } \\
\text { Main }\end{array}$} & None & 0.009005 & $\begin{array}{c}17.58601[2] \\
(0.3724)\end{array}$ & 25.87211 & 31.15385 \\
\cline { 2 - 6 } & At most 1 & 0.000491 & $\begin{array}{c}0.906113[2] \\
(0.9995)\end{array}$ & 12.51798 & 16.55386 \\
\hline
\end{tabular}

$* * *, * *$ symbolize the significance levels of $\% 1$ and \%5 respectively, ( ) represents MacKinnon-HaugMichelis (1999) p-values, [ ] represents Lag lengths for models

Table 7. Johansen Cointegration Test Results-Maximum Eigen Statistics (RUSSIA)

\begin{tabular}{|c|c|c|c|c|c|}
\hline Models & $\begin{array}{c}\text { Number of } \\
C E(s)\end{array}$ & $\begin{array}{l}\text { Eigen } \\
\text { Value }\end{array}$ & Max Eigen Value & $\begin{array}{c}\% 5 \\
\text { Critical } \\
\text { Value }\end{array}$ & $\begin{array}{c}\% 1 \text { Critical } \\
\text { Value }\end{array}$ \\
\hline \multirow{2}{*}{$\begin{array}{l}\text { Oil Price - } \\
\text { MOEX Main }\end{array}$} & None & 0.011210 & $\begin{array}{c}20.62999^{* * *}[3] \\
(0.0083)\end{array}$ & 15.89210 & 20.16121 \\
\hline & At most 1 & 0.004199 & $\begin{array}{c}7.699972[3] \\
(0.0941)\end{array}$ & 9.164546 & 12.76076 \\
\hline \multirow{2}{*}{$\begin{array}{l}\text { Oil Price - } \\
\text { MOEX } \\
\text { Chemicals }\end{array}$} & None & 0.010776 & $\begin{array}{c}21.14966^{* *}[2] \\
(0.0275)\end{array}$ & 19.38704 & 23.97534 \\
\hline & At most 1 & 0.003329 & $\begin{array}{c}6.509100[2] \\
(0.3985)\end{array}$ & 12.51798 & 16.55386 \\
\hline \multirow{2}{*}{$\begin{array}{l}\text { Oil Price - } \\
\text { MOEX } \\
\text { Consumer } \\
\text { Goods \& } \\
\text { Services }\end{array}$} & None & 0.008340 & $\begin{array}{c}16.63281[5] \\
(0.1202) \\
\end{array}$ & 19.38704 & 23.97534 \\
\hline & At most 1 & 0.001923 & $\begin{array}{c}3.822331[5] \\
\quad(0.7677)\end{array}$ & 12.51798 & 16.55386 \\
\hline \multirow{2}{*}{$\begin{array}{l}\text { Oil Price - } \\
\text { MOEX Electric } \\
\text { Utilities }\end{array}$} & None & 0.009708 & $\begin{array}{c}16.75020^{* *}[4] \\
(0.0366)\end{array}$ & 15.89210 & 20.16121 \\
\hline & At most 1 & 0.004088 & $\begin{array}{c}7.033573[4] \\
(0.1246)\end{array}$ & 9.164546 & 12.76076 \\
\hline \multirow{2}{*}{$\begin{array}{l}\text { Oil Price - } \\
\text { MOEX } \\
\text { Financials }\end{array}$} & None & 0.013122 & $\begin{array}{c}24.17187^{* * *}[3] \\
(0.0020)\end{array}$ & 15.89210 & 20.16121 \\
\hline & At most 1 & 0.002588 & $\begin{array}{c}4.742693[3] \\
(0.3128) \\
\end{array}$ & 9.164546 & 12.76076 \\
\hline \multirow{2}{*}{$\begin{array}{c}\text { Oil Price - } \\
\text { MOEX } \\
\text { Manufacturing }\end{array}$} & None & 0.004088 & $\begin{array}{c}7.672067[7] \\
(0.5872)\end{array}$ & 15.89210 & 18.52001 \\
\hline & At most 1 & 0.003830 & $\begin{array}{c}7.187013 \text { [7] } \\
(0.1169)\end{array}$ & 9.164546 & 6.634897 \\
\hline $\begin{array}{c}\text { Oil Price - } \\
\text { MOEX Metals \& }\end{array}$ & None & 0.012106 & $\begin{array}{l}22.28920^{* * *}[3] \\
(0.0043)\end{array}$ & 15.89210 & 20.16121 \\
\hline
\end{tabular}


H. Kurtar - A. Kapusuzoglu - N.B. Ceylan 11/1 (2019) 558-574

\begin{tabular}{|c|c|c|c|c|c|}
\hline Mining & At most 1 & 0.004078 & $\begin{array}{c}7.477936[3] \\
(0.1034)\end{array}$ & 9.164546 & 12.76076 \\
\hline $\begin{array}{c}\text { Oil Price - } \\
\text { MOEX Oil \& } \\
\text { Gas }\end{array}$ & None & 0.019200 & $\begin{array}{c}29.13765^{* * *}[6] \\
(0.0003)\end{array}$ & 15.89210 & 20.16121 \\
\cline { 2 - 6 } & At most 1 & 0.004053 & $\begin{array}{c}6.104422[6] \\
(0.1828)\end{array}$ & 9.164546 & 12.76076 \\
\hline \multirow{2}{*}{$\begin{array}{c}\text { Oil Price - } \\
\text { MOEX Telecoms }\end{array}$} & None & 0.010626 & $\begin{array}{c}22.48744^{* *}[3] \\
(0.0171)\end{array}$ & 19.38704 & 23.97534 \\
\cline { 2 - 6 } & At most 1 & 0.002248 & $\begin{array}{c}4.736592[3] \\
(0.6345)\end{array}$ & 12.51798 & 16.55386 \\
\hline $\begin{array}{l}\text { Oil Price - } \\
\text { MOEX } \\
\text { Transport }\end{array}$ & At most 1 & 0.002110 & $\begin{array}{c}3.471736[6] \\
(0.4964)\end{array}$ & 9.164546 & 12.76076 \\
\cline { 2 - 6 }
\end{tabular}

Table 8. Johansen Cointegration Test Results-Maximum Eigen Statistics (USA)

\begin{tabular}{|c|c|c|c|c|c|}
\hline Models & $\begin{array}{c}\text { Number of } \\
\text { CE(s) }\end{array}$ & $\begin{array}{l}\text { Eigen } \\
\text { Value }\end{array}$ & Max Eigen Value & $\begin{array}{c}\% 5 \text { Critical } \\
\text { Value }\end{array}$ & $\begin{array}{c}\text { \%1 Critical } \\
\text { Value }\end{array}$ \\
\hline \multirow{2}{*}{$\begin{array}{l}\text { Oil Price - SP500 } \\
\text { Index }\end{array}$} & None & 0.001468 & $\begin{array}{c}3.558450[3] \\
(0.9762)\end{array}$ & 15.89210 & 20.16121 \\
\hline & At most 1 & 0.000544 & $\begin{array}{c}1.317817[3] \\
(0.9047)\end{array}$ & 9.164546 & 12.76076 \\
\hline \multirow{2}{*}{$\begin{array}{c}\text { Oil Price - SP500 } \\
\text { Consumer } \\
\text { Discretionary }\end{array}$} & None & 0.005930 & $\begin{array}{c}14.16645[3] \\
(0.2432)\end{array}$ & 19.38704 & 23.97534 \\
\hline & At most 1 & 0.001318 & $\begin{array}{c}3.141749[3] \\
(0.8592)\end{array}$ & 12.51798 & 16.55386 \\
\hline \multirow{2}{*}{$\begin{array}{l}\text { Oil Price - SP500 } \\
\text { Consumer Staples }\end{array}$} & None & 0.002727 & $\begin{array}{c}6.504902[3] \\
(0.7294) \\
\end{array}$ & 15.89210 & 20.16121 \\
\hline & At most 1 & 0.001094 & $\begin{array}{c}2.608516[3] \\
(0.6561)\end{array}$ & 9.164546 & 12.76076 \\
\hline \multirow{2}{*}{$\begin{array}{c}\text { Oil Price - SP500 } \\
\text { Energy }\end{array}$} & None & 0.002033 & $\begin{array}{c}5.007215[3] \\
(0.8877)\end{array}$ & 15.89210 & 20.16121 \\
\hline & At most 1 & 0.000514 & $\begin{array}{c}1.264138[3] \\
(0.9134)\end{array}$ & 9.164546 & 12.76076 \\
\hline \multirow{2}{*}{$\begin{array}{l}\text { Oil Price - SP500 } \\
\text { Financials }\end{array}$} & None & 0.002566 & $\begin{array}{c}6.451576[7] \\
(0.7358) \\
\end{array}$ & 15.89210 & 20.16121 \\
\hline & At most 1 & 0.001023 & $\begin{array}{c}2.571151[7] \\
(0.6634) \\
\end{array}$ & 9.164546 & 12.76076 \\
\hline \multirow{2}{*}{$\begin{array}{c}\text { Oil Price - SP500 } \\
\text { Health Care }\end{array}$} & None & 0.003840 & $\begin{array}{c}9.164800[3] \\
(0.4163) \\
\end{array}$ & 15.89210 & 20.16121 \\
\hline & At most 1 & 0.000719 & $\begin{array}{c}1.713253[3] \\
(0.8338) \\
\end{array}$ & 9.164546 & 12.76076 \\
\hline \multirow{2}{*}{$\begin{array}{l}\text { Oil Price - SP500 } \\
\text { Industrials }\end{array}$} & None & 0.001361 & $\begin{array}{c}3.227521[2] \\
(0.9860)\end{array}$ & 15.89210 & 20.16121 \\
\hline & At most 1 & 0.000448 & $\begin{array}{c}1.061794[2] \\
(0.9434)\end{array}$ & 9.164546 & 12.76076 \\
\hline \multirow{2}{*}{$\begin{array}{c}\text { Oil Price - SP500 } \\
\text { Information } \\
\text { Technology }\end{array}$} & None & 0.003647 & $\begin{array}{c}8.659374[2] \\
(0.4712) \\
\end{array}$ & 15.89210 & 20.16121 \\
\hline & At most 1 & 0.000659 & $\begin{array}{c}1.562294[2] \\
(0.8621)\end{array}$ & 9.164546 & 12.76076 \\
\hline $\begin{array}{c}\text { Oil Price - SP500 } \\
\text { Materials }\end{array}$ & None & 0.001602 & $\begin{array}{c}3.799983 \text { [2] } \\
(0.9667) \\
\end{array}$ & 15.89210 & 20.16121 \\
\hline
\end{tabular}


H. Kurtar - A. Kapusuzoglu - N.B. Ceylan 11/1 (2019) 558-574

\begin{tabular}{|c|c|c|c|c|c|}
\hline & At most 1 & 0.000295 & $\begin{array}{c}0.698336[2] \\
(0.9828)\end{array}$ & 9.164546 & 12.76076 \\
\hline \multirow{2}{*}{$\begin{array}{c}\text { Oil Price - SP500 } \\
\text { Real Estate }\end{array}$} & None & 0.001246 & $\begin{array}{c}2.984596[2] \\
(0.9911)\end{array}$ & 15.89210 & 20.16121 \\
\cline { 2 - 6 } & At most 1 & 0.000532 & $\begin{array}{c}1.274228[2] \\
(0.9118)\end{array}$ & 9.164546 & 12.76076 \\
\hline \multirow{2}{*}{$\begin{array}{c}\text { Oil Price-SP500 } \\
\text { Telecom Services }\end{array}$} & None & 0.001432 & $\begin{array}{c}3.340657[4] \\
(0.9830)\end{array}$ & 15.89210 & 20.16121 \\
\cline { 2 - 6 } & At most 1 & 0.000511 & $\begin{array}{c}1.191979[4] \\
(0.9246)\end{array}$ & 9.164546 & 12.76076 \\
\hline \multirow{2}{*}{$\begin{array}{c}\text { Oil Price-SP500 } \\
\text { Utilities }\end{array}$} & None & 0.001533 & $\begin{array}{c}3.672178[2] \\
(0.9720)\end{array}$ & 15.89210 & 20.16121 \\
\cline { 2 - 6 } & At most 1 & 0.000393 & $\begin{array}{c}0.940516[2] \\
(0.9588)\end{array}$ & 9.164546 & 12.76076 \\
\hline
\end{tabular}

Table 9. Johansen Cointegration Test Results-Maximum Eigen Statistics (CANADA)

\begin{tabular}{|c|c|c|c|c|c|}
\hline Models & $\begin{array}{l}\text { Number } \\
\text { of } C E(s)\end{array}$ & Eigen Value & $\begin{array}{l}\text { Max Eigen } \\
\text { Value }\end{array}$ & $\begin{array}{c}\text { \%5 Critical } \\
\text { Value }\end{array}$ & $\begin{array}{c}\% 1 \text { Critical } \\
\text { Value }\end{array}$ \\
\hline \multirow{2}{*}{$\begin{array}{l}\text { Oil Price - TSX } \\
\quad \text { Energy }\end{array}$} & None & 0.004305 & $\begin{array}{c}10.80390[7] \\
(0.2667)\end{array}$ & 15.89210 & 20.16121 \\
\hline & At most 1 & 0.001528 & $\begin{array}{c}3.828433[7] \\
(0.4382)\end{array}$ & 9.164546 & 12.76076 \\
\hline \multirow{2}{*}{$\begin{array}{l}\text { Oil Price - TSX } \\
\text { Financials }\end{array}$} & None & 0.001798 & $\begin{array}{c}4.509087[7] \\
(0.9267)\end{array}$ & 15.89210 & 20.16121 \\
\hline & At most 1 & 0.000257 & $\begin{array}{c}0.644917 \text { [7] } \\
(0.9868) \\
\end{array}$ & 9.164546 & 12.76076 \\
\hline \multirow{2}{*}{$\begin{array}{c}\text { Oil Price - TSX } \\
\text { Health Care }\end{array}$} & None & 0.002559 & $\begin{array}{c}6.424499[4] \\
(0.7390)\end{array}$ & 15.89210 & 20.16121 \\
\hline & At most 1 & 0.001041 & $\begin{array}{c}2.609944[4] \\
(0.6558)\end{array}$ & 9.164546 & 12.76076 \\
\hline \multirow{2}{*}{$\begin{array}{l}\text { Oil Price - TSX } \\
\text { Industrial }\end{array}$} & None & 0.001812 & $\begin{array}{c}4.549764[2] \\
(0.9238)\end{array}$ & 15.89210 & 20.16121 \\
\hline & At most 1 & 0.000873 & $\begin{array}{c}2.191882[2] \\
(0.7393)\end{array}$ & 9.164546 & 12.76076 \\
\hline \multirow{2}{*}{$\begin{array}{l}\text { Oil Price - TSX } \\
\text { Information } \\
\text { Technology }\end{array}$} & None & 0.002365 & $\begin{array}{c}5.941974[2] \\
(0.7944) \\
\end{array}$ & 15.89210 & 20.16121 \\
\hline & At most 1 & 0.000190 & $\begin{array}{c}0.477940[2] \\
(0.9956)\end{array}$ & 9.164546 & 12.76076 \\
\hline \multirow{2}{*}{$\begin{array}{l}\text { Oil Price - TSX } \\
\text { Materials }\end{array}$} & None & 0.006525 & $\begin{array}{c}16.42578^{* *}[3] \\
(0.0412)\end{array}$ & 15.89210 & 20.16121 \\
\hline & At most 1 & 0.002755 & $\begin{array}{c}6.921828[3] \\
(0.1306)\end{array}$ & 9.164546 & 12.76076 \\
\hline \multirow{2}{*}{$\begin{array}{l}\text { Oil Price - TSX } \\
\text { Real Estate }\end{array}$} & None & 0.001157 & $\begin{array}{c}2.905640[2] \\
(0.9924)\end{array}$ & 15.89210 & 20.16121 \\
\hline & At most 1 & 0.000197 & $\begin{array}{c}0.495213[2] \\
(0.9949)\end{array}$ & 9.164546 & 12.76076 \\
\hline \multirow{2}{*}{$\begin{array}{l}\text { Oil Price - TSX } \\
\text { REIT }\end{array}$} & None & 0.001718 & $\begin{array}{c}3.785418[2] \\
(0.9673)\end{array}$ & 15.89210 & 20.16121 \\
\hline & At most 1 & 0.000670 & $\begin{array}{c}1.474692[2] \\
(0.8779)\end{array}$ & 9.164546 & 12.76076 \\
\hline $\begin{array}{l}\text { Oil Price - TSX } \\
\text { Composite Index }\end{array}$ & None & 0.002226 & $\begin{array}{c}5.587821[7] \\
(0.8323)\end{array}$ & 15.89210 & 20.16121 \\
\hline
\end{tabular}


H. Kurtar - A. Kapusuzoglu - N.B. Ceylan 11/1 (2019) 558-574

\begin{tabular}{|c|c|c|c|c|c|}
\hline & At most 1 & 0.000276 & $\begin{array}{c}0.692559[7] \\
(0.9833)\end{array}$ & 9.164546 & 12.76076 \\
\hline $\begin{array}{c}\text { Oil Price - TSX } \\
\text { Composite } \\
\text { Discretionary }\end{array}$ & None & 0.001769 & $\begin{array}{c}4.442434[2] \\
(0.9312)\end{array}$ & 15.89210 & 20.16121 \\
\cline { 2 - 6 } & At most 1 & 0.000555 & $\begin{array}{c}1.393673[2] \\
(0.8920)\end{array}$ & 9.164546 & 12.76076 \\
\hline $\begin{array}{c}\text { Oil Price - TSX } \\
\text { Consumer } \\
\text { Staples }\end{array}$ & None & 0.004495 & $\begin{array}{c}11.28568[6] \\
(0.2314)\end{array}$ & 15.89210 & 20.16121 \\
\cline { 2 - 6 } & At most 1 & 0.001885 & $\begin{array}{c}4.725382[6] \\
(0.3149)\end{array}$ & 9.164546 & 12.76076 \\
\hline $\begin{array}{c}\text { Oil Price - TSX } \\
\text { Telecom. } \\
\text { Services }\end{array}$ & At most 1 & 0.002193 & $\begin{array}{c}4.524327[1] \\
(0.9256)\end{array}$ & 15.89210 & 20.16121 \\
\cline { 2 - 6 } & None & 0.001663 & $\begin{array}{c}3.750964[7] \\
(0.9688)\end{array}$ & 15.89210 & 20.16121 \\
\cline { 2 - 6 } Oil Price - TSX \\
Utilities
\end{tabular}

Table 10. Johansen Cointegration Test Results-Maximum Eigen Statistics (JAPAN)

\begin{tabular}{|c|c|c|c|c|c|}
\hline Models & $\begin{array}{c}\text { Number of } \\
\text { CE(s) }\end{array}$ & $\begin{array}{l}\text { Eigen } \\
\text { Value }\end{array}$ & Max Eigen Value & $\begin{array}{c}\% 5 \text { Critical } \\
\text { Value }\end{array}$ & $\begin{array}{c}\text { \%1 Critical } \\
\text { Value }\end{array}$ \\
\hline \multirow{2}{*}{$\begin{array}{c}\text { Oil Price - } \\
\text { TOPIX } 17 \text { Auto } \\
\text { \& Transport } \\
\text { Equipment }\end{array}$} & None & 0.000887 & $\begin{array}{c}1.452605[4] \\
(1.0000)\end{array}$ & 15.89210 & 20.16121 \\
\hline & At most 1 & 5.15E-06 & $\begin{array}{c}0.008430[4] \\
(1.0000)\end{array}$ & 9.164546 & 12.76076 \\
\hline \multirow{2}{*}{$\begin{array}{l}\text { Oil Price - } \\
\text { TOPIX } 17 \\
\text { Banks }\end{array}$} & None & 0.013255 & $\begin{array}{c}18.80181[4] \\
(0.0607)\end{array}$ & 19.38704 & 23.97534 \\
\hline & At most 1 & 0.000133 & $\begin{array}{c}0.187472[4] \\
(1.0000)\end{array}$ & 12.51798 & 16.55386 \\
\hline \multirow{2}{*}{$\begin{array}{c}\text { Oil Price - } \\
\text { TOPIX } 17 \\
\text { Commerce } \\
\text { Wholesale } \\
\text { Trade } \\
\end{array}$} & None & 0.002192 & $\begin{array}{c}3.667325[2] \\
(0.9721)\end{array}$ & 15.89210 & 20.16121 \\
\hline & At most 1 & 0.000703 & $\begin{array}{c}1.175850[2] \\
(0.9270)\end{array}$ & 9.164546 & 12.76076 \\
\hline \multirow{2}{*}{$\begin{array}{c}\text { Oil Price - } \\
\text { TOPIX } 17 \\
\text { Construction } \\
\text { Materials }\end{array}$} & None & 0.009028 & $\begin{array}{c}15.15453[2] \\
(0.1854)\end{array}$ & 19.38704 & 23.97534 \\
\hline & At most 1 & 0.000302 & $\begin{array}{c}0.504258[2] \\
(1.0000)\end{array}$ & 12.51798 & 16.55386 \\
\hline \multirow{2}{*}{$\begin{array}{c}\text { Oil Price - } \\
\text { TOPIX } 17 \\
\text { Electrc App \& } \\
\text { Prec Instrmnt }\end{array}$} & None & 0.008386 & $\begin{array}{c}14.07248[2] \\
(0.2493)\end{array}$ & 19.38704 & 23.97534 \\
\hline & At most 1 & 0.000314 & $\begin{array}{c}0.523984[2] \\
(1.0000) \\
\end{array}$ & 12.51798 & 16.55386 \\
\hline \multirow{2}{*}{$\begin{array}{c}\text { Oil Price - } \\
\text { TOPIX } 17 \\
\text { Electric Power } \\
\& \text { Gas } \\
\end{array}$} & None & 0.005686 & $\begin{array}{c}9.528089[2] \\
(0.3793)\end{array}$ & 15.89210 & 20.16121 \\
\hline & At most 1 & 0.000353 & $\begin{array}{c}0.590431[2] \\
(0.9902) \\
\end{array}$ & 9.164546 & 12.76076 \\
\hline \multirow{2}{*}{$\begin{array}{l}\text { Oil Price - } \\
\text { TOPIX } 17 \\
\text { Foods }\end{array}$} & None & 0.001188 & $\begin{array}{c}1.985922[2] \\
(0.9995)\end{array}$ & 15.89210 & 20.16121 \\
\hline & At most 1 & $6.48 \mathrm{E}-05$ & $\begin{array}{c}0.108278[2] \\
(1.0000)\end{array}$ & 9.164546 & 12.76076 \\
\hline $\begin{array}{c}\text { Oil Price - } \\
\text { TOPIX } 17 \text { IT \& }\end{array}$ & None & 0.000551 & $\begin{array}{c}0.780948[4] \\
(1.0000)\end{array}$ & 15.89210 & 20.16121 \\
\hline
\end{tabular}


H. Kurtar - A. Kapusuzoglu - N.B. Ceylan 11/1 (2019) 558-574

\begin{tabular}{|c|c|c|c|c|c|}
\hline $\begin{array}{c}\text { Services \& } \\
\text { Others }\end{array}$ & At most 1 & 0.000138 & $\begin{array}{c}0.196298[4] \\
(1.0000)\end{array}$ & 9.164546 & 12.76076 \\
\hline \multirow{2}{*}{$\begin{array}{l}\text { Oil Price - } \\
\text { TOPIX } 17 \\
\text { Machinery }\end{array}$} & None & 0.000887 & $\begin{array}{c}1.482884[2] \\
(1.0000) \\
\end{array}$ & 15.89210 & 20.16121 \\
\hline & At most 1 & 0.000462 & $\begin{array}{c}0.771857[2] \\
(0.9766)\end{array}$ & 9.164546 & 12.76076 \\
\hline \multirow{2}{*}{$\begin{array}{c}\text { Oil Price - } \\
\text { TOPIX } 17 \\
\text { Pharmaceutical }\end{array}$} & None & 0.000925 & $\begin{array}{c}1.544439[2] \\
(0.9999)\end{array}$ & 15.89210 & 20.16121 \\
\hline & At most 1 & 8.69E-05 & $\begin{array}{c}0.145089 \text { [2] } \\
(1.0000)\end{array}$ & 9.164546 & 12.76076 \\
\hline \multirow{2}{*}{$\begin{array}{c}\text { Oil Price - } \\
\text { TOPIX } 17 \text { Raw } \\
\text { Materials \& } \\
\text { Chemicals }\end{array}$} & None & 0.010837 & $\begin{array}{c}15.45029[4] \\
(0.1704)\end{array}$ & 19.38704 & 23.97534 \\
\hline & At most 1 & 0.000145 & $\begin{array}{c}0.206253[4] \\
(1.0000)\end{array}$ & 12.51798 & 16.55386 \\
\hline \multirow{2}{*}{$\begin{array}{c}\text { Oil Price - } \\
\text { TOPIX } 17 \text { Real } \\
\text { Estate }\end{array}$} & None & 0.001267 & $\begin{array}{c}2.112844[2] \\
(0.9991)\end{array}$ & 15.89210 & 20.16121 \\
\hline & At most 1 & 0.000535 & $\begin{array}{c}0.892409[2] \\
(0.9644) \\
\end{array}$ & 9.164546 & 12.76076 \\
\hline \multirow{2}{*}{$\begin{array}{c}\text { Oil Price - } \\
\text { TOPIX } 17 \\
\text { Retail Trade }\end{array}$} & None & 0.000747 & $\begin{array}{c}1.247931[2] \\
(1.0000)\end{array}$ & 15.89210 & 20.16121 \\
\hline & At most 1 & 0.000369 & $\begin{array}{c}0.617037[2] \\
(0.9886) \\
\end{array}$ & 9.164546 & 12.76076 \\
\hline \multirow{2}{*}{$\begin{array}{c}\text { Oil Price - } \\
\text { TOPIX } 17 \text { Steel } \\
\text { \& Nonferrous } \\
\text { Metals }\end{array}$} & None & 0.024992 & $\begin{array}{c}27.73879^{* * *}[7] \\
(0.0005)\end{array}$ & 15.89210 & 20.16121 \\
\hline & At most 1 & 0.000227 & 0.248396 & 9.164546 & 12.76076 \\
\hline \multirow{2}{*}{$\begin{array}{c}\text { Oil Price - } \\
\text { TOPIX } 17 \\
\text { Transportation } \\
\text { \& Logistics }\end{array}$} & None & 0.000361 & $\begin{array}{c}0.657812[1] \\
(1.0000) \\
\end{array}$ & 15.89210 & 20.16121 \\
\hline & At most 1 & 0.000294 & $\begin{array}{c}0.535311[1] \\
(0.9932) \\
\end{array}$ & 9.164546 & 12.76076 \\
\hline \multirow{2}{*}{$\begin{array}{l}\text { Oil Price - } \\
\text { TOPIX } 17 \text { Main }\end{array}$} & None & 0.009005 & $\begin{array}{c}16.67990[2] \\
(0.1185) \\
\end{array}$ & 19.38704 & 23.97534 \\
\hline & At most 1 & 0.000491 & $\begin{array}{c}0.906113[2] \\
(0.9995)\end{array}$ & 12.51798 & 16.55386 \\
\hline
\end{tabular}

***, ** symbolize the significance levels of $\% 1$ and $\% 5$ respectively, ( ) represents MacKinnon-HaugMichelis (1999) p-values, [ ] represents Lag lengths for models 